\title{
CONSIDERATIONS ON URBAN AND BLOCK FORMATION OF THE OLD QUARTER IN CADIZ
}

\author{
カディス旧市街の都市形成と街区構成に関する考察

\begin{abstract}
Juan Ramon JIMENEZ VERDEJO*, Jesús Alberto PULIDO ARCAS ** and Shuji FUNO***
\end{abstract} \\ J.R. ヒメネスベルデホ, J.A. プリドアルカス，布野修司
}

\begin{abstract}
This paper aims to clarify the process of historical evolution and the main characteristics of the morphology of urban tissues in the old town of Cadiz. The authors did extensive field work and research in this area in the year 2009, documenting 88 heritage buildings. Also, historical records from 2.217 buildings available in the planning office of Cadiz have also been taken into account in this research. In this paper, historical maps have been studied in order to elucidate the urban formation and evolution of this old town. Also, the main characteristics of the urban morphology are clarified by overlapping the historical formation process and an analysis of the current state of this old town. This paper concludes the characteristics of spatial formation of the old town in Cadiz in relation with the street system, block alteration and building density.
\end{abstract}

Keywords : Cadiz, urban formation, urban tissues, fortification, street system カディス, 都市形成, 都市組織, 要塞, 街路体系

\section{Objectives.}

This paper aims to clarify the urban and block formation of the old quarter in Cadiz, which is located in the South of Spain (Fig.1), based on fieldworks and analysis of historical maps. Authors discuss the features of Cadiz old quarter, which present peculiar characteristics in terms of urban form.

The fieldworks were conducted from January 2009 to November 2009 for the assessment of the heritage properties in San Francisco area, northwards the old quarter; 88 heritage properties were assessed during 10 months. Field surveyors visited the sites to take photographs, collected historical documents, including interviews to the inhabitants and drawing of block and dwellings. Also, data collection about urban elements was performed: Street width was measured on-site; building height was established taking into account the number of floors, taking as a mean value 4 meters for ground floor and 3 meters for the rest of floors. Both parameters were contrasted with available data from CAD and GIS files from the planning office of Cadiz.

All the data of this fieldwork were included in Cadiz PGOU (Plan General de Ordenación Urbana), which is an urban development plan that acts as the leading policy for urban planning in the municipality ${ }^{1)}$. With reference to the heritage properties in the old city, there are available records for 2.217 residential buildings with different protection categories, which provide with an extensive database of the whole area ${ }^{2}$.

The outcome of this fieldwork gave support to the hypothesis that the urban morphology and the housing typology in Cadiz do not match the usual pattern in Southern Spain. This state may supported by the peculiar historical, geographical and climatic conditions for this city.

Previous research by the authors in this field was mainly focused on the environmental performance of the extant housing typology in the old quarter of Cádiz ${ }^{3), 4), 5)}$.

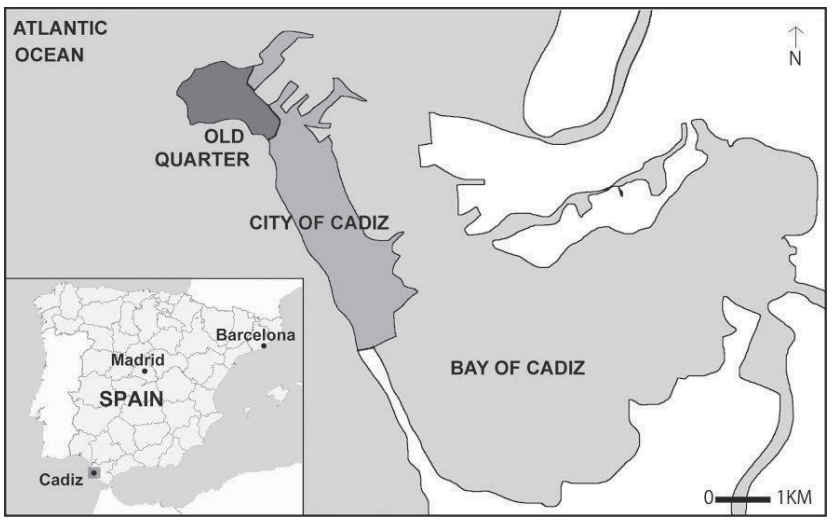

Fig. 1 Location of the city of Cadiz within Spain
* Assoc. Prof., Graduate School of environmental planning, University of Shiga Prefecture., Ph.D.

* Canon Foundation Fellow, Visiting Researcher, University of Shiga Prefecture. Ph.D.

*** Nihon University Research Prof., Dr. Eng
滋賀県立大学環境料研究料 淮教授・博士 (芸術工学)

キャノン財団研究員・滋賀県立大学客員研究員・博士

日本大学 特任教授. 工博 


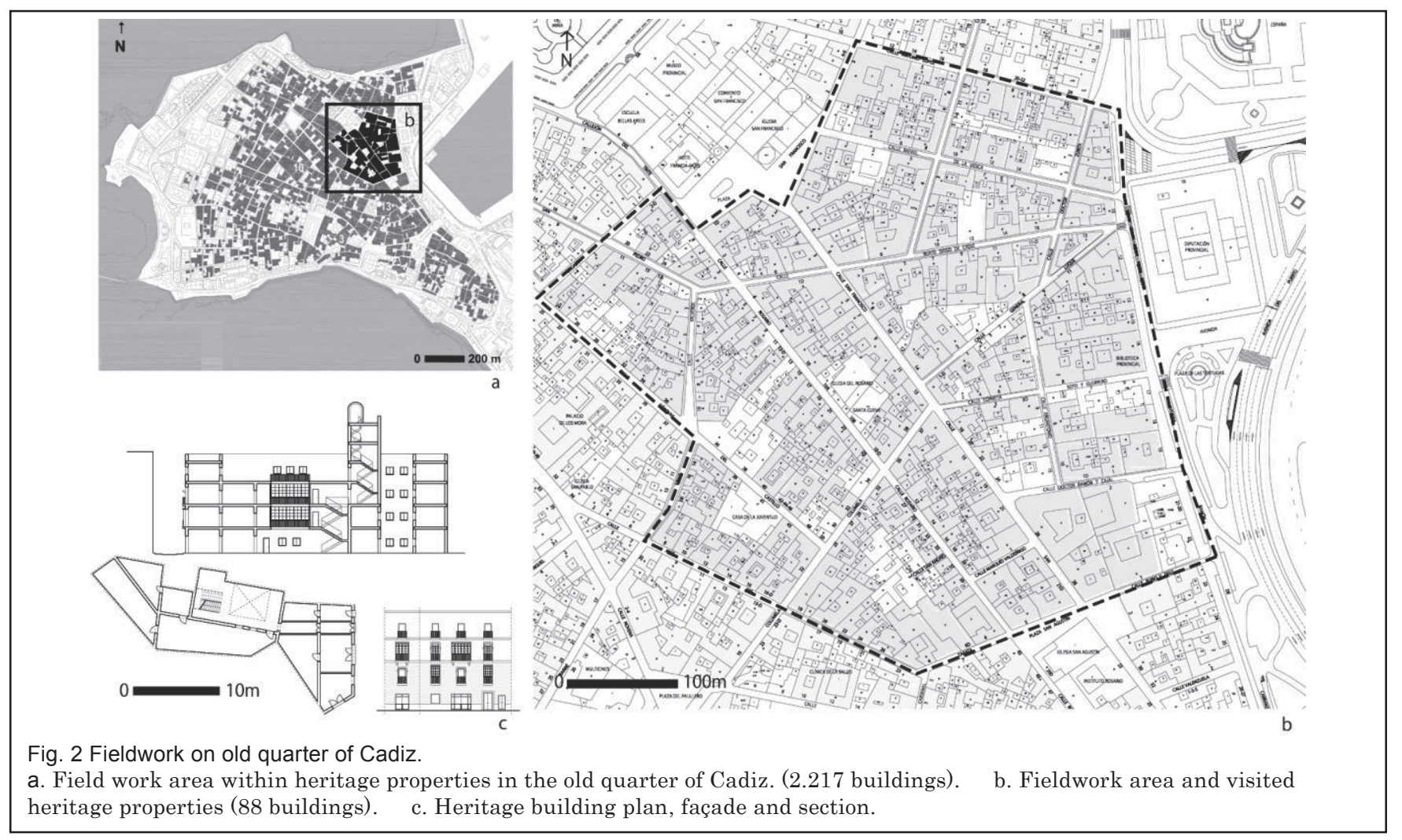

Available materials are focused on different elements of this old quarter. Fortification system is a major asset to discuss the historic urban development of Cadiz ${ }^{6), 7), 8)}$. Extensive description about the historical process that has driven the formation and evolution of housing typology in Cadiz has already been addressed in previous researches 9). Moreover, descriptive studies about urban landscape based on historical records provides us with information about urban morphology at a specific period 10),11)

This material provides with valuable information, but lacks discussion about urban morphology as an entity that interrelates all elements of urban design (streets, buildings, blocks...) For this reason, it was considered worth doing further research on this matter.

The objectives of the research focus on the clarification of the formation of the urban structure of the old quarter of Cadiz, which includes the following:

1) Establish a chronological evolution of the urban tissue of Cadiz and the fortifications system; identify the link between both structures.

2) Identify the remaining urban structures from each chronological epoch that pervades in the urban conglomerate.

3) Clarify a current state of the old quarter in terms of urban morphology, which includes building height, urban blocks and street design patterns, in relation with the two former points.

\section{Urban formation of Cadiz}

According to archaeological surveys, the city of Cadiz has been inhabited since the VII Century B.C by the Phoenicians, as well as after by the Romans ${ }^{* 1 .}$. However, these vestiges were erased and replaced by the medieval citadel. Historical evolution of this city differs from other counterparts in South Spain, as the majority of the surviving urban structure of Cadiz dates from the 17 th century to the $19^{\text {th }}$ century. The earlier city has been consistently transformed by the development of the commercial harbour ${ }^{1)}$, as a hub of rich trade in commodities and ideas derived from alien influences.

In order to clarify historical formation of the urban tissue, extensive material compiled as historical archives has been used. As for plans and maps, AGS (Archivo General de Simancas) 14) has 635 plans and maps of Cadiz, and SGE (Servicio Geográfico del Ejército) has 19 items ${ }^{15)}$; In the ICC (Institut Cartographic de Catalunya), 125 items about Cadiz were found ${ }^{16)}$. Amongst this extensive visual material, six historical views are useful to reconstruct the transformation process of Cadiz in relation with the main historical events.

Aditional material is useful to make a figure of urban morphology at a given time 9),11): Inventory of historical names of streets public spaces in reference to their adjacent buildings ${ }^{12)}$ population census, housing taxes records or administrative division of the old city .

The formation and evolution of Cadiz is described as follows:

a) 1513: The oldest picture recorded of the city of Cadiz dates back to 1513 (Fig.3.a). The prominent elements can be identified are the old castle and the medieval wall (Fig. 4.a, 01-04), the old castle (B) and Santa Catalina Church (C), in the 


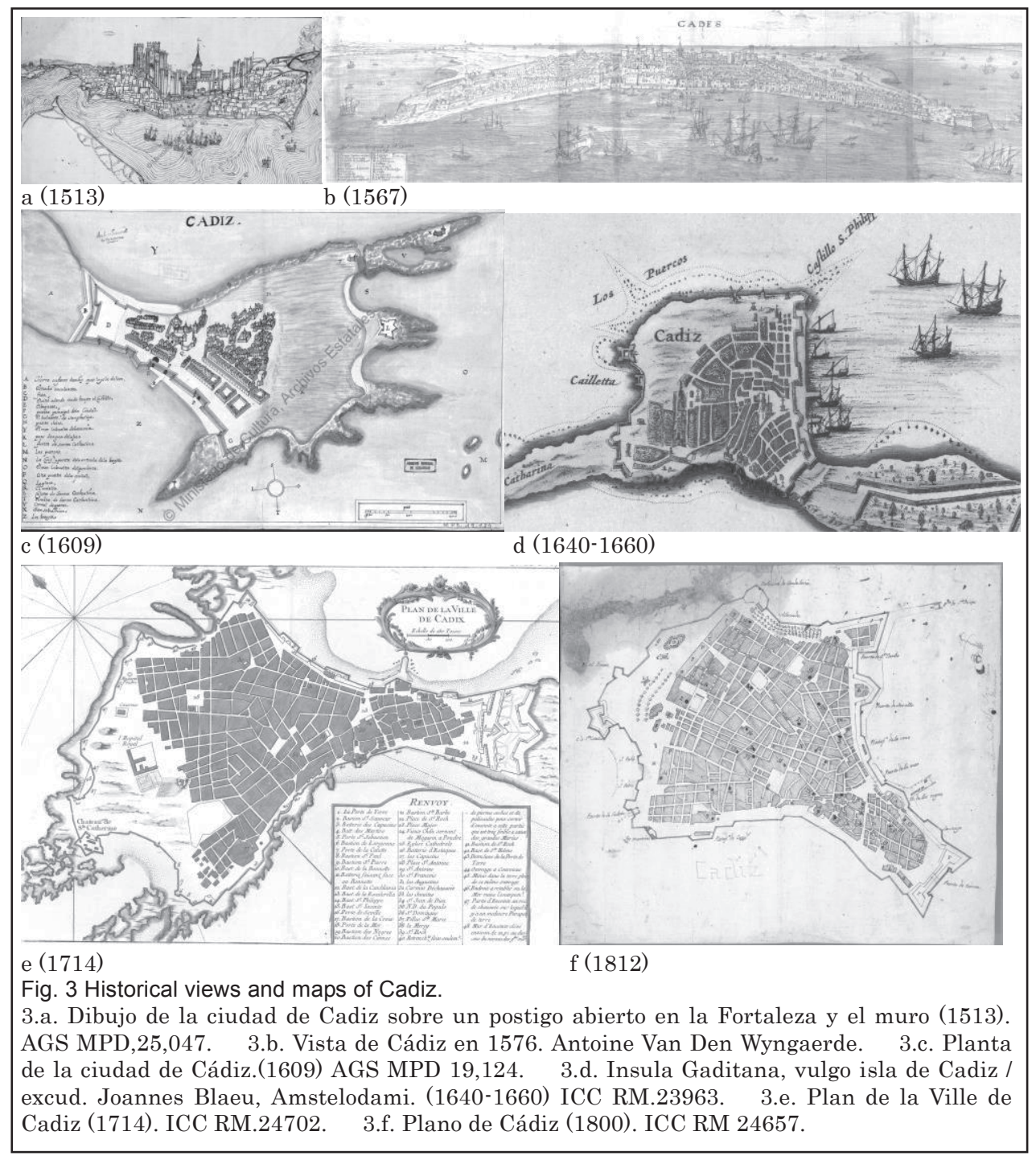

place where nowadays stands the Santa Catalina bastion (18) Oldest traceable urban structures of Cadiz appear in this image, that is, the arrabal (historic suburb) of Santiago in the West side and the arrabal of El Pópulo, East side. Falcón Márquez states that at that time Cadiz would hold a population lesser than 5.000 inhabitants ${ }^{* 2}$.). Also, near Plaza de la Corredera (A), the oldest urban public space that remains intact, the oldest traceable plots can be identified ${ }^{* 3}$.), according to the historical works by Suárez-Cantón Huertas 9).

b) 1567: The image drawn by Antoine Van Den Vingaerde (Fig.3.b) shows an urban structure embracing the inner harbour, where Cadiz would benefit from trading. Urban development of outer suburbs is notorious. The San Francisco Convent (D) constitutes a remarkable landmark in the city, comprising the church, the convent itself and the adjacent urban space, Plaza San Francisco. Historical records from the works by Adolfo de Castro ${ }^{12)}$ proved that an old mill located nearby in (E), which dates back from 1550, was the seed of an emerging urban structure whose traces would emerge from previous orchards. Plaza de la Candelaria (F), dated from at least 1567, would be outlined next to a Convent with the same name. At that time the population gradually increased, surpassing 5.000 inhabitants ${ }^{*} 4$.).

c) 1609: In 1596, after many unsuccessful attempts, a fleet commanded by English Rovert Devereux captured Cadiz during the Anglo-Spanish war, obliterating the city ${ }^{*_{5}}$ ); this means a crucial breakpoint, which puts an end to the medieval urban structure of Cadiz and set the basis for the modern urban development (Fig. 4.c). The old medieval walls (01-04) are demolished and the effort focus on rebuilding the city, thus urban expansion is not very notorious in this period, only visible towards the inner harbour. Traceable structures links existing city with San Francisco Convent (D) and an incipient urban development can be seen around (E); urban expansion towards East produce a new representative public space, the Los Descalzos Convent with its adjacent orchards, depicted as an urban void (G). After the siege, further discussion was held amongst planners and military engineers about the most suitable system in order to protect Cadiz; a fortification system that would defend only half of the Peninsula was outlined ${ }^{9)}$, but finally works for a whole defensive system ${ }^{*} 6$.) planned by Cristobal de Rojas, which surrounded the entire peninsula, broke ground 7) ${ }^{*}$.) First strategic points to defend were the mainland connection, solved by elements (05-07) and the inner harbour, with a defensive line (09-16). After these drastic changes, the population of the city would be around 10.000 inhabitants.

d)1640-1660: Progressive development of the urban structure was accomplished after the 1596 siege. Development faces West side of the peninsula (Fig.3.d). This incipient development adopts low density plots, with built fronts to the street, and orchards in the back; this, together with historical records ${ }^{12}$, lead to identify incipient urban structures such as the ones surrounding (E), which previously existed, Mina square $(\mathrm{H})$, another public space adjacent to San Francisco 


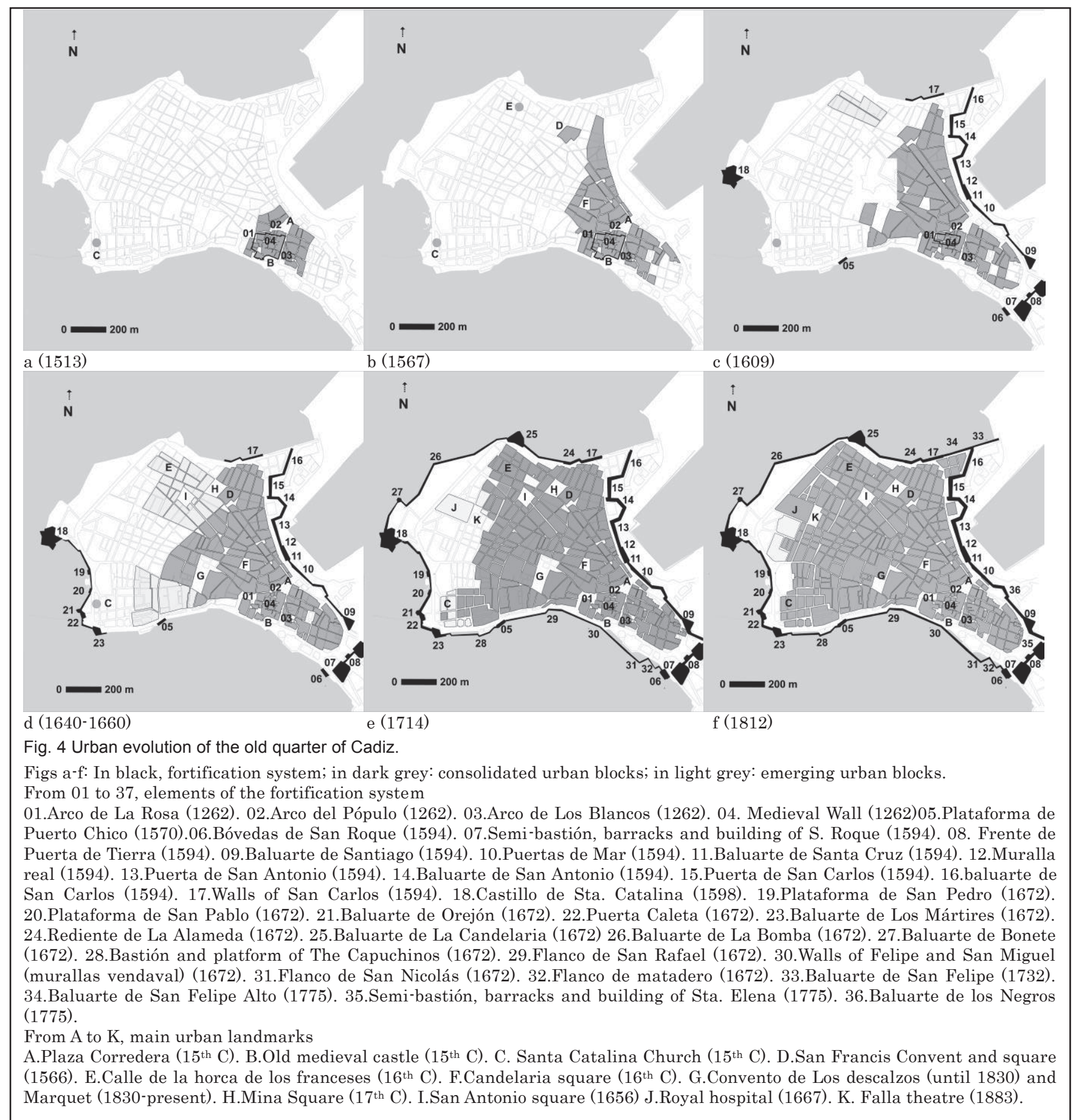

Convent and San Antonio Square (I); This area features a new urban tissue with straight streets and uniform plot sizes. Also, westwards from (G), an incipient urban development is emerging. The expansion of the defensive system faces open sea, with the construction of elements (18-23). Another attack towards Cadiz in 1625 *.) resulted in a failure for the English; this fact gave the population a sense of security and Cadiz population rose up to approximately 22.000 inhabitants.

e) 1714: The urban structure of Cadiz in the beginning of $18^{\text {th }}$ Century is shaped by an important historical event. The trade with America was shared between Sevilla and Cadiz from 1680 *9.) and the city extended towards West, filling the emerging plots that were previously outlined. The city became denser, producing the characteristic urban structure with noble houses in the West area of the Peninsula. This can be clearly seen in Fig.4.e around (E), which is now a consolidated compact urban tissue; also, new residential developments built around the former Santa Catalina Church (C) would be outlined as planned extensions of the city. In the historical view is also depicted Royal Hospital (J), which marks the limit for the future urban sprawl westwards. Nearby it can be seen the outline of Falla square (K), one of the most remarkable urban spaces in the Westside of Cadiz. By this time fortification system is completed and surrounds the entire peninsula. 


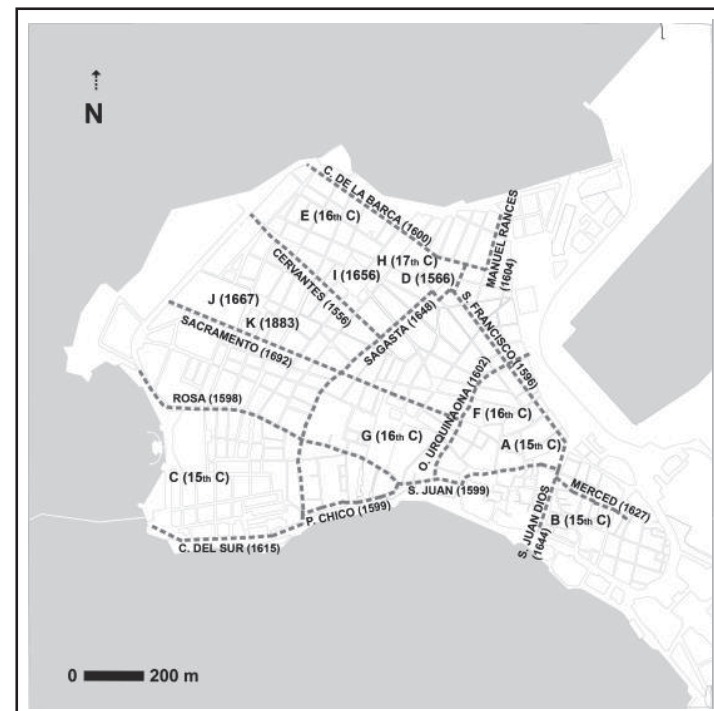

Fig. 5 Main urban landmarks and streets (2013)

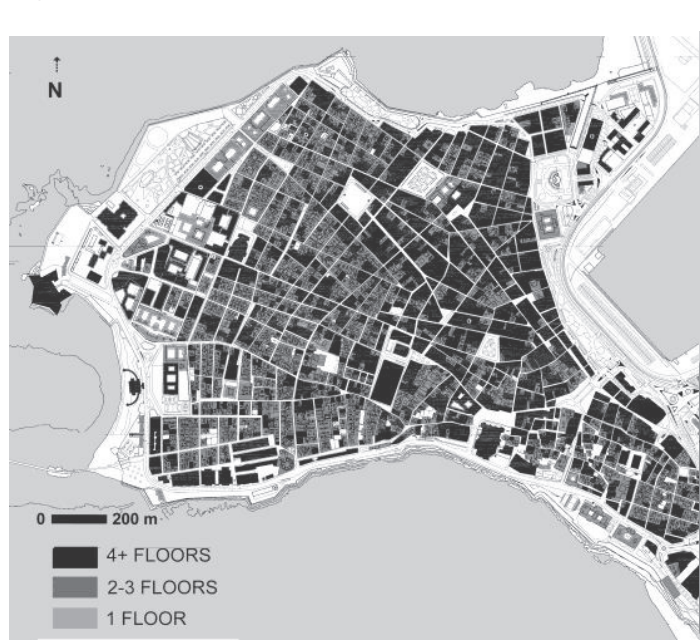

Fig. 7 Building height (2013)

Nearly reaching the maximum expansion, the city population at that time would be around 40.000 inhabitants.

f) 1812: The urban tissue has reached its limit in the West (Fig. 3.f), and the remaining void spaces would be used as military compounds, parks and seaside promenades. The new urban structures in this period are greatly influenced by the publication in 1792 of the building ordinances ${ }^{13)}$ that would require for all buildings a façade and plan design in order to obtain a building permit, thus producing new areas with regular plot sizes and uniform building heights, mainly in the West area. Moreover, these ordinances combined with the commercial and economic outburst of the city, due to the monopoly of the trade with America from 1717, would produce a profound renovation of the existing building stock; it was a common trend at that time to add additional floors to existing buildings and reform the façade. In this period, the old city hold the maximum population recorded up-to-date: 74.500 inhabitants. This, in turn, means one of the most densely populated old cities in Spain; according to Suarez-Canton ${ }^{9}$, during the French siege in 1812, some authors claim that the city could have house about 100.000 inhabitants, but only due to

exceptional

circumstances ${ }^{*} 10$.).

From the beginning of $19^{\text {th }}$ Century the old city is considered to reach its full capacity in terms of building extension, and the urban structure, as recognized nowadays, is formed. Cadiz would be enclosed by walls for nearly 400 years, and urban sprawl would not surpass its fortification until late 1930's, nearly 400 years later than many Spanish cities ${ }^{* 11 .)}$.

3. Block formation of the old quarter of Cadiz.

In order to clarify the block formation and the urban evolution in this city, the following elements have been studied: Main urban public spaces and streets, block transformation, building height, street width and fortification system.

(1) Fig. 5 depicts the main urban landmarks and streets that have shaped the evolution of old Cadiz, together with their approximate year of origin according to historical records. The spots help to trace back the main vectors that have driven urban sprawl in old Cadiz, with aid from figures 4 a-f. The oldest urban space (A) connects with point (C) Sta. Catalina church by natural pathways like S. Juan St. (1599), P. Chico St. (1599), Campo del Sur St. (1615) and Rosa St. (1598), which was know before as road to Sta. Catalina Castle; S. Juan de Dios St. (1644) and Merced St. (1627) provides easy access to historic suburbs. Early development of S. Francisco St. (1596) as a straight line is explained as it gives easy access Northbound, parallel to the inner harbour and also to (D) S. Francisco Convent, the second religious order to establish a compound in $1566{ }^{*}{ }^{12 .}$ An old mill in (E) explains that early existence of C. de la Barca St. (1600), Manuel Rances St. (1604) and Cervantes St. (1566), which derive from old pathways 
delimiting orchards. Plaza de la Candelaria (F), annexed to Convento de la Candelaria (1567), reformed on 1873 after the dismantling of the convent, set the spot for an early development of blocks in $16^{\text {th }} \mathrm{C}$, and reformed during $17^{\text {th }} \mathrm{C}$; O. Urquinaona St. (1602) provided this space with the North-South connection between open sea (S. Juan St.) and inner harbour (S. Francisco St.). Eastwards this area a limit is set by Sagasta St, whose curved outline is a consequence of the traces of an old pathway adapted to topography and the connection that provided between Baluarte de Puerto Chico (05) and S. Francisco Convent (D); its origin dates back to 1648 and its layout was gradually extended Northbound and Southbound, constituting a ring road around the existing city. Public space (G) has been an activity hub in the South area, since the establishment of Convento de los Descalzos (until 1830), and after that it was dismantled, so room was made for a new public square where a public market was built. Sacramento St. (1692) set a straight line for latter developments around (J) in 1667 and (K) in 1883. San Antonio square (I) (1656) was laid out on purpose during the planned urban expansion of 1650-1700 with a regular form that has pervaded until present time, in contrast with squares (A), (F) and (G), which were the product of many historical affairs affecting its form and space configuration.

(2) Fig. 6 depicts altered urban blocks. Criteria for alteration has been set in terms of maintaining their original shape from their inception to present time. Historical records and views, as well as date of layout of streets have been contrasted to compose this map. Three main zones can be devised: A unaltered central core, dating back from medieval age; a first urban belt, which appeared between 1550-1660 and was heavily reformed and split further on, by means of street alignments and openings; an outer belt, in the form of planned districts that appeared since 1700 approximately and that pervades unaltered today.

(3) Fig. 7 shows old city in terms of number of floors, in relation with urban density. It can be pointed out the difference between the Northwest area, with prevailing 4-story buildings, and the West area, where 2-3-story are predominant. Commercial expansion during $17^{\text {th }} \mathrm{C}$ and consequent urban reformation give support to this density in the proximity of the inner harbor, where the most representative urban manors are located; this dense area matches a temporal span for urban development ranging from second half of $16^{\text {th }} \mathrm{C}$ to first third of $17^{\text {th }} \mathrm{C}$, when it was conformed, and from second half of $17^{\text {th }} \mathrm{C}$ to the beginning of $18^{\text {th }} \mathrm{C}$, when it was heavily reformed. West area is formed by planned developments, comprising mainly tenant buildings with lower density.

(4) Fig. 8 analyses street width; this pattern is ought to be understood together with Fig. 6, as block renovation is inextricably linked to streets that were widened, opened and realigned. Streets narrower than 4 meters can only be found in

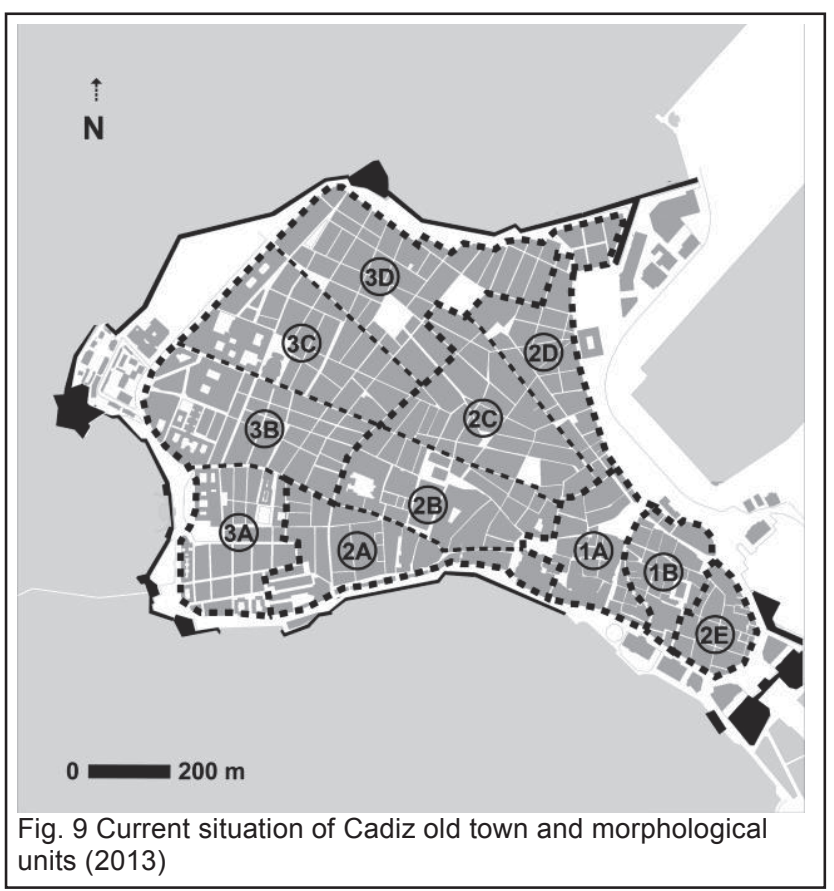

the medieval core, which was mainly unaltered, and subsequent urban expansion from early $17^{\text {th }} \mathrm{C}$, delimiting heavily altered urban blocks. 4-5 meters wide streets are found in the inner and outer urban belt, mainly from O. Urquinaona St, Sagasta St. and further on, concurring with urban development from $17^{\text {th }} \mathrm{C}$. Later expansion from this point predominantly consists on 5-8 meters wide streets, and streets wider than 8 meters, so that they are found almost exclusively in planned neighborhoods from the last decades of $17^{\text {th }} \mathrm{C}$ and $18^{\text {th }} \mathrm{C}$.

(5) With regard to the fortification system, only small traces of the medieval wall remain (Fig.4 01-04) as it was abandoned after devising the new fortification in 1596. Parts of the modern fortification (Fig.4 08 to 14 and 36) were demolished in 1912 in order to enhance the expansion of the inner harbor and to make room for new buildings (Fig.4 29-31) in the $20^{\text {th }}$ Century. Nevertheless, they still remained as the main urban landmark in this city.

Combining these variables in the analysis, three main urban pervading structures in Cadiz have been identified, with its subsequent subdivisions:

(1) Central medieval core: Formation of this area can be traced back to $15^{\text {th }} \mathrm{C}$ and spans to first half of $16^{\text {th }} \mathrm{C}$, though it had been altered through time; morphologically, it is characterized by a typical medieval urban tissue, with irregular blocks, narrow and intricate streets (Fig. 10.a). Two subareas can be outlined attending block alteration. 1A, the very urban core of Cadiz matching the inner city inside medieval walls, is unaltered, (Fig. 10.b); only 15,4\% of block surface has been altered from its inception. In contrast, subarea 1B has $94 \%$ of its block area as altered. In terms of building height no clear 


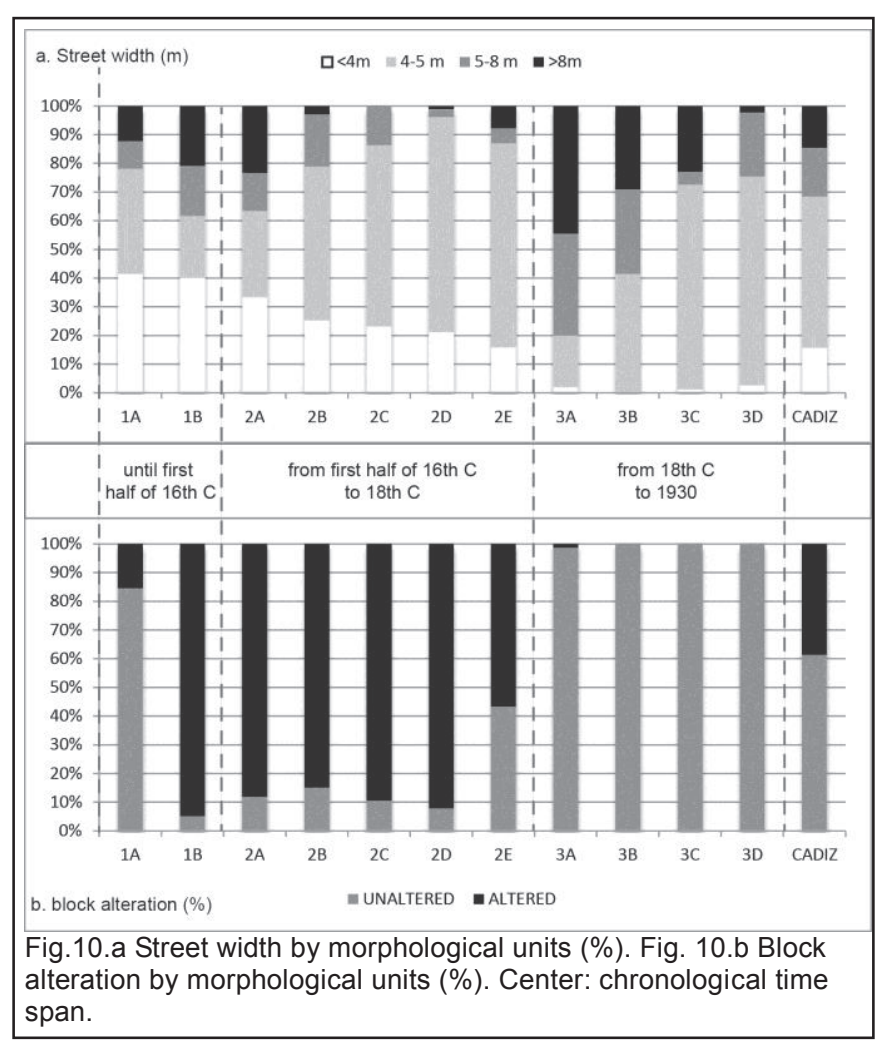

distinction can be made between them.

(2) Inner urban belt: This area was occupied from the second half of the $16^{\text {th }} \mathrm{C}$ to the beginning of the $18^{\text {th }} \mathrm{C}$, and was heavily reformed during subsequent decades. It comprises several notorious streets (S. Juan, P. Chico, S. Francisco) that provides with direct access to West area. It features heavily reformed urban blocks, medium-width streets $(4-5 \mathrm{~m})$ and medium to high urban density (2-3, 4 floors). It is subdivided in 5 subareas, which can be distinguished in terms of urban density and street width. Block alteration is evident in all subsectors (Fig. 10.b) (2A 88,1\%, 2B $84,9 \%, 89,3 \%, 2 \mathrm{D} 92,1 \%, 2 \mathrm{E} 56,6 \%)$ but a difference can be made in $2 \mathrm{E}$, due to its strategic position next to the mainland connection. In terms of street width (Fig. 10.a), a pattern can be found from North to South, as the predominance of medium width streets (4-5m) from $2 \mathrm{~A}(30,1 \%), 2 \mathrm{~B}(53,6 \%), 2 \mathrm{C}(63,2 \%)$ and $2 \mathrm{D}(75 \%)$ at the expense of narrow streets $(33,3 \%, 25,3 \%, 23,2 \%$, $21,2 \%$ respectively). This fact, together with the predominance of taller buildings (4+ floors) mostly in subsectors $2 \mathrm{C}$ and $2 \mathrm{D}$ define the North area of the inner belt as denser but with broader streets. In this sense, sector $2 \mathrm{E}$, at the East side of the inner belt, present similar morphology as sector $2 \mathrm{D}$ in terms of street width, with a predominance of $4-5 \mathrm{~m}$ wide streets $(71,1 \%)$.

(3) Outer belt: Time span for his area began at the beginning of the $18^{\text {th }} \mathrm{C}$ and lasted until 1930. Despite ancient streets exists in this area (Rosa St, 1615; C. de la Barca St. 1600) from previous rural pathways, its development is subsequent. In terms of block transformation the four subsectors are homogeneous. No block transformation is found in $3 \mathrm{~B}, 3 \mathrm{C}$ and $3 \mathrm{D}$, and only in $3 \mathrm{~A}$ a small amount is altered (1,3\%) (Fig. 10.b). Building height (Fig. 7) and street width (Fig. 8) together clarify several differences in the four subsectors. $3 \mathrm{~A}$ and $3 \mathrm{~B}$ are characterized by lower density and predominance for broad streets. Ways wider than $5 \mathrm{~m}$ represent $80 \%$ out of the total in $3 \mathrm{~A}$ and $58,5 \%$ in $3 \mathrm{~B}$, whereas only $28,4 \%$ in $3 \mathrm{C}$ and $24,5 \%$ in $3 \mathrm{D}$ (Fig. 10.a). According to Fig. 7, building height in 3D is similar to that one found in the inner belt, but the other 3 subsectors have predominance for 2-3 floors blocks. Also, in all subsectors of the outer belt streets narrower than 4 meters are nearly inexistent ( $2 \%$ in $3 \mathrm{~A}, 0 \%$ in $3 \mathrm{~B}, 1,3 \%$ in $3 \mathrm{C}$ and $2,7 \%$ in $3 \mathrm{D}$ ). The internal differences between all subsectors are due to the chronological gap; 3D, as the earlier development, is denser than the rest, being $3 \mathrm{~A}$ the less dense as one of the latest districts to be developed.

\section{Conclusions}

(1) Urban morphology in the city of Cadiz differs from its counterparts in South Spain, due to specific historical, geographical and environmental circumstances. Its inexistence as a prevailing city before $17 \mathrm{C}$, its later development in $17 \mathrm{C}$, the presence of fortifications and the geographical limitation of the peninsula explain the absence of some historical tissues and the presence of others very characteristic.

(2) Three main urban morphological units, with their correspondent subunits, have been identified in terms of urban morphology: street design, block alteration and building density.

(3) These main morphological units have been related accordingly to three definite time chronological time spans: Until first half of $16^{\text {th }} \mathrm{C}$; from first half of $16^{\text {th }} \mathrm{C}$ to $18^{\text {th }} \mathrm{C}$; from 18 ${ }^{\text {th }} \mathrm{C}$ to 1930.

(4) Urban density in Cadiz can be explained based on two facts:

It does not respond to a lack of physical space, but to a desire of renovation and congestion around the main activity hub of commerce that was the inner harbor in $16^{\text {th }}$ and $17^{\text {th }} \mathrm{C}$, which produced in turn new and dense urban tissues.

- The historical decision to undertake the project by Cristobal de Rojas determined Cadiz to be a dense city, expanding itself in height inside the walls until 1930, rather than a dense nucleus inside the walls surrounded by low-density historic suburbs, as usual in Southern Spain.

These conclusions pose new questions about residential building types in old Cadiz that will be addressed in a subsequent paper.

\section{Acknowledgments}

The authors would like to thank Arch. Carlos Rubio Bellido from University of Seville and Arch. Antonio Galindo Riaño 
from the city planning office of Cadiz for its indispensable support in the fieldwork and in the elaboration of this research.

Notes

*1.) According to historical records from the Roman author Veleyo Paterculo, the ancient city of Gadir could have been founded in the year 1.104 B.C,. However, there are no archeological evidence that can prove this hypothesis, so that it is established that Cadiz was inhabited from $5^{\text {th }}$ Century.

*2.) According to Suarez Canton, the population would be around 5000 inhabitants, but other authors (Sancho, H. Estructura y perfil de mografico de la ciudad de Cadiz en el S. XVI) claim that it would surpass 1200 inhabitants.

*3.) These plots still remain in its original size. They feature a front of 15 varas (around $12.45 \mathrm{~m}$ ) and 17 varas (around $14.11 \mathrm{~m}$ ) from front to back, giving a plot size between 200-300 sqm.

*4.) According to historical records (I. Porquincho Moya) in this Century the population would increase gradually: 3.550 inhabitants in 1550 and 7.100 inhabitants in 1.600 ,

*5.) The works by Pedro de Abreu (Historia del saqueo de Cadiz por los ingleses) give a detailed description about the parlous state of the city after the battle.

*6.) The modern walls in Cadiz were, in fact, part of a whole defensive system that was planned to cover the Atlantic Coast of Andalusia, protecting the ships that came from America.

*7.) This decision was, in fact, crucial and determined the latter development of Cádiz as a fortified city. Some authors state that this decision was supported by the fact that Spanish Royal Court feared not only foreign attacks, but also internal rebellion form the numerous foreign population living in Cadiz; others claim that the main reason was the convenience of defending Cadiz basically by sea, because once enemy could set foot on land, siege of the city would be unavoidable.

*8.) Between November $1^{\text {st }}$ and November $7^{\text {th }}, 10.000$ men and 90 ships tried to capture one Spanish city and the ships coming from America. Finally Cadiz was chosen as their objective.

*9.) From 1680, the ships coming from America had the obligation of stopping in Cadiz before going to Sevilla; later, in 1717, the Casa de Contratacion was definitely transferred to Cadiz.

*10.) During the Spanish Independence war, between 1808 and 1814, Cadiz was the only city that was not controlled by the French. In Cadiz, parliamentarians from the whole nation gathered and the national assembly proclaimed the first Spanish Constitution in 1812. The city resisted the French attacks during 2 years.

*11.) Other Southern Spanish historical cities can account for having historic suburbs out of their fortifications, such as Triana in Sevilla $\left(15^{\text {th }} \mathrm{C}\right)$, Santiago and San Miguel in Jerez de la Frontera $\left(16^{\text {th }} \mathrm{C}\right)$ or Saqundain Córdoba $\left(8^{\text {th }} \mathrm{C}\right)$.

*12.) The first religious order to establish headquarters in Cadiz was the Jesuits in 1564.

\section{References}

1) Rubio-Bellido, Carlos, Galindo Riaño, José Antonio: The fortifications in the town planning of Cadiz, Subcatálogo de edificaciones protegidas, PGOU de Cádiz, 2011.9.

2) VV.AA: Plan General de Ordenación Urbana (PGOU) de Cádiz, 2011.9.

3) Rubio Bellido C, Pulido Arcas JA, Cabeza Lainez, JM: Heritage architecture and its relation with the climate, Proceedings of Green cities 3rd national summit on energy efficiency in building and urban design, pp 70-83, 2012.11.

4) Rubio Bellido C, Pulido Arcas JA, Cabeza Lainez, JM: Techniques of environmental analysis applied to the urban heritage of Cadiz, Proceedings of the $3^{\text {rd }}$ International Conference on Heritage and Sustainable Development Greenlines Institute for sustainable development, pp 71-80, 2010.6.
5) Rubio-Bellido, Carlos: Valores ambientales de la arquitectura histórica en la ciudad de Cádiz: Estrategias para la rehabilitación, Doctoral Thesis, Sevilla, 2014.10

6）渡邊春香・杉本俊多: 16 年世紀カデイスの海辺の都市景観，日本 建築学会中国支部研究報告集，第 33 巻平成 2010.3 .

7) Rubio-Bellido, Carlos. Ureta Grajera, María: The master plan of fortifications as a management tool for the conservation and development of the defence heritage of Cádiz, WIT Transactions on The Built Environment, Vol 143, WIT Press, pp 25-36, 2014.9.

8) C. Rubio Bellido, P. Gallego Pérez \& R. Llácer Pantión: The future of fortifications in the city of Cádiz: Opportunities and strategies for urban regeneration, Defence sites 2014. WIT Transactions on The Built Environment, Vol 123, pp 135-147, 2012.6.

9) Suárez-Canton Huertas, Miguel: La casa gaditana: Análisis de un proceso de evolución y creación tipológica, Doctoral Thesis, Seville, 1996.3.

10）高柳伸一: 1596 年奇襲後のカディスにおける工兵クリストバル . デ・ロハス活動に関して, 日本建築学会計画系論文集 第 74 巻 第 635 号, pp. 273-281, 2009.01.

11) Falcón Márquez, Teodoro: Iconografía: territorio y ciudad en el Cádiz del S. XVI. Trocadero, revista de historia moderna y contemporánea, Vol 16, pp 501-506, 2003.6.

12) Castro, Adolfo de: Nombres antiguos de las calles y plazas de Cádiz sus orígenes, sus cambios sucesos notables ocurridos en ellas, idea de las antiguas costumbres locales por un individuo de la Academia Española de Arqueología, Cádiz, 1857.

13) Ordenanzas de policía de la ciudad de Cádiz de 1792. Digital copy available online at the archives of the polytechnic University of Madrid, 2014.9.

14) Digitalized maps and plans available at Spanish Ministry of Culture and Education, 2014.9

15) Digitalized maps and plans available at Instituto Geográfico Nacional (IGN), 2014.9.

16) Digitalized maps and plans available at Institut Geográphic de Catalunya, 2014.10.

\section{和文要約}

本論文は、スペイン、カディスの旧市街の形成過程と街区構成の 特徴を臨地調查と歴史地図をもとに明らかにすることを目的とし ている。著者たち（J.A. プリドアルカス）は、2009年のほぼ一年 にわたってカディスのサン・フランシスコ地区について詳細調査を 行い、8 8 軒の実測を行った。このデータを含むカディス全体 2.217 軒の実測図面およびセヴィージャの国立総合公文書（AEG）などが 所有する歴史的地図が本稿の考察のもとになっている。

本稿では、まず、残された歴史的地図をもとに、その歴史の画 期を確認しながら、その都市形成過程を明らかにした。そして、現 状の街路体系および建造物の階数の分布図にその都市形成過程を 重ねることで、カディス全体の空間構成および地区ごとの特性を明 らかにした。カディスが立地するのが半島であり、その形態が要塞 と城壁のシステムによって境界づけられていること、すなわち、郊 外一の拡張ができないことが決定的である。極めて高密度の居住形 態が生み出されていることにおいて他の南スペインの都市とは異 なる。街路体系が時代毎に改変されていること、すなわち、拡幅さ れ、直線化される過程も他の都市にはみられない。結果として、カ ディスに特徴的な建築類型が成立している。この建築類型と街区形 態の関係については別稿としたい。

(2014 年 10 月 30 日原稿受理, 2015 年 4 月 6 日採用決定 